\title{
Recent patent applications related to molecular cloning
}

Patent \#

WO 200387330

(1)

WO 200383075

thent

WO 200378582

\section{US 20030157661}

(

\section{ES 2189608}

DE 10160600

US 20030104388

EP 1298212

EP 1298212

\section{US 20030017594 A method for cloning DNA molecules in cells comprising} employing RecT-mediated homologous recombination within chemically competent cells.
A new bacterial artificial chromosome (BAC) comprising an entire viral genome in a circular form with a head-to-tail concatemer junction and sequences for plasmid replication in Escherichia coli inserted in the viral genome in a nonessential site; useful in a VAC-BAC shuttle vector system for creating recombinant poxviruses from the DNA cloned from BAC.

A method for analyzing genomic DNA clones, particularly the expression and screening of genomic DNA sequences encoding uncharacterized genes and proteins comprising retrovirus-based genomic screening.

A method for identifying a novel nucleotide sequence, comprising obtaining a sequence for a portion of the DNA clone, where the length of the sequence is less than one-third of the length of the clone; useful for characterizing genetic diversity in an organism, and for identifying bacterial genes with commercial relevance.

\section{A method of inserting DNA into a recipient genome; useful for} inserting the DNA fragment which is used as scaffold in the Bacillus subtilis genome for cloning DNA.

A de novo synthesized plasmid comprising at least a replication origin and a selection marker gene; useful for making other plasmids or for DNA cloning, amplification, gene expression, gene therapy or DNA immunization.

A method of producing an immunostimulant for fish farming consisting of the molecular cloning of an interleukin- $1 \beta$ recombinant of Sparus aurata $L$., for use in vaccination. DNA inserts.

A new isolated DNA coding for the AsiSI restriction endonuclease or AsiSI methylase; useful for cleaving DNA molecules into small fragments for molecular cloning and gene characterization.

An isolated DNA segment coding for the $B s m B I$ restriction endonuclease and/or BsmBI methylase obtainable from Bacillus stearothermophilus B61; useful in molecular cloning and gene characterization. inated by the insertion of a coding sequence;
Assignee

US Government

Domi A

Moss B

\begin{tabular}{lll} 
Inventor(s) & $\begin{array}{l}\text { Priority } \\
\text { application } \\
\text { date }\end{array}$ & $\begin{array}{l}\text { Publication } \\
\text { date }\end{array}$ \\
\hline $\begin{array}{l}\text { Domi A, } \\
\text { Moss B }\end{array}$ & $8 / 9 / 2002$ & $10 / 23 / 2003$ \\
& &
\end{tabular}

Bleck GT,
Bremel R

$3 / 26 / 2003$

$10 / 9 / 2003$

(Middleton, Bremel RD,

WI, USA) Eakle K,

Imboden M

Athenix Carozzi N, 3/11/2002 9/25/2003

(Durham, NC, Carr B,

USA) Duck NB,

Hargiss T,

Koziel MG

\begin{tabular}{|c|c|c|c|}
\hline Mitsubishi & - & 3/1/2002 & $9 / 9 / 2003$ \\
\hline
\end{tabular}

(Tokyo)

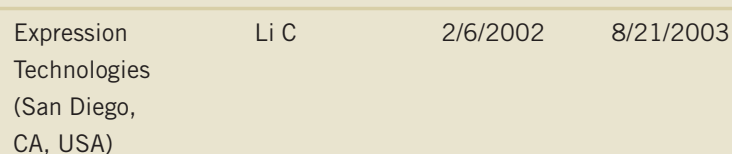

University of

$11 / 28 / 2000 \quad 7 / 1 / 2003$

Murcia (Spain)

GL BioTech Graupner S $\quad$ 12/10/2001 6/26/2003

(Bremen,

Germany)

$\begin{array}{llll}\text { New England } & \text { Xu S, } & 9 / 20 / 2001 & 6 / 5 / 2003 \\ \text { Biolabs (Beverly, } & \text { Zhou J, } & \\ \text { MA, USA) } & \text { Zhu Z } & \end{array}$

$\begin{array}{llll}\text { New England } & \text { Dore A, } & \text { 9/28/2001 } & \text { 4/3/2003 } \\ \text { Biolabs (Beverly, } & \text { Hume A, } & & \\ \text { MA, USA) } & \text { Pellitier J, } & \\ & \text { Xu S, } \\ & \text { Zhou J, } & & \\ & \text { Pelletier J } & & \\ & \text { Francis SA, } & \text { 7/20/2001 } & \text { 1/23/2003 } \\ \text { Francis SA; } & \text { Joep MPP, } & \\ \text { Joep MPP; } & \text { Youming Z, } & \\ \text { Youming Z; } & \text { Muijrers JPP, } & \\ \text { Muijrers JPP; } & \text { Stewart FA, } & \\ \text { Stewart FA; } & \text { Zhang Y } \\ \text { Zhang Y } & \end{array}$

Source: Derwent Information, Alexandria, VA. The status of each application is slightly different from country to country. For further details, contact Derwent Information, 1725 Duke Street, Suite 250, Alexandria, Va 22314. Tel: 1 (800) DERWENT (info@derwent.com). 